\title{
Whole Cell PatchClamp Electrophysiology in Opsin- Expressing Brain Slice with Visible Lights or UCNPs
}

\section{Yueguang Si ( $\nabla$ sczx514@163.com )}

Yiting Wang

\section{Method Article}

Keywords: Patch-clamp

Posted Date: September 27th, 2021

DOl: https://doi.org/10.21203/rs.3.pex-1627/v1

License: (c) (i) This work is licensed under a Creative Commons Attribution 4.0 International License. Read Full License 


\section{Abstract}

It describes the flow of whole cell patch-clamp electrophysiology in mice brain slice.

\section{Introduction}

\section{Reagents}

1.Artificial cerebrospinal fluid (ACSF) : $119 \mathrm{mM}$ sodium chloride, $2.5 \mathrm{mM}$ potassium chloride, $26 \mathrm{mM}$ sodium bicarbonate, $12.5 \mathrm{mM}$ D-glucose, $5 \mathrm{mM}$ HEPES, $2 \mathrm{mM}$ calcium chloride, $2 \mathrm{mM}$ magnesium chloride and $1.25 \mathrm{mM}$ sodium phosphate monobasic monohydrate $(\mathrm{pH} 7.3)$.

2.Internal solution : $105 \mathrm{mM}$ potassium gluconate, $5 \mathrm{mM}$ potassium chloride, $0.5 \mathrm{mM}$ calcium chloride, 2 $\mathrm{mM}$ magnesium chloride, $5 \mathrm{mM}$ ethylene glycol-bis (2-aminoethylether)-N,N,N',N'-tetraacetic acid, $2 \mathrm{mM}$ adenosine 5 '-triphosphate magnesium salt, $0.5 \mathrm{mM}$ guanosine 5 '-triphosphate sodium salt hydrate,7 $\mathrm{mM}$ phosphocreatine disodium salt hydrate and $10.0 \mathrm{mM}$ HEPES. pH 7.2, osmolarity $280 \mathrm{mOsm}$.

\section{Equipment}

Sutter P97, X-cite Illuminator, Multiclamp 700B amplifier, Digidata 1440 digitizer

\section{Procedure}

1. Mouse was anesthetized with isoflurane.

2. Mouse was perfused with $4^{\circ} \mathrm{C}$ ACSF.

3. Brain was cut and immersed in uniform ice-ACSF mixtures.

4. Brain was dissected, dehydrated and glued on to a plate as soon as possible.

5. Brain was transferred into uniform ice-ACSF mixtures bubbled with carbogen (95\% oxygen and $5 \%$ carbon dioxide).

6. 250-um-thick slices were obtained and transferred into $37^{\circ} \mathrm{C}$ ACSF.

7. Thick-walled borosilicate glass (Sutter BF150-86-10) electrodes were pulled (Sutter P97) to a resistance of 5-7 M $\Omega$.

8. Fill the electrodes with internal solution.

9. Electrode was moved to approach the neuron. 
10. The neuron was patched.

11. For visible light, it was filtered to $470 \mathrm{~nm}, 546 \mathrm{~nm}$ and $665 \mathrm{~nm}$ through microscope. Light power was controlled through X-cite Illuminators and light pulse was adjust to $1 \mathrm{~s}$.

12. For NIR lasers (808 nm, $980 \mathrm{~nm}$ and $1532 \mathrm{~nm})$, they were delivered through Optical fiber.

13. UCNPs illuminant were fixed in the form of transparent polymethylpropanamide (PMMA) film.

14. Specifically to preparation, $1 \mathrm{~mL}$ UCNPs stock solution were re-dispersed to $4 \mathrm{~mL}$ chloroform with With $0.40 \mathrm{~g}$ dissolved PMMA. The solid UCNP film was then obtained by dripping solution on the cover glass and completely evaporating the chloroform solvent.

15. The brain slice was placed onto the UCNP film.

16. The activity was recorded. 